\title{
THE INFLUENCE OF CABLE SAG ON THE DYNAMIC BEHAVIOUR OF CABLE-STAYED SUSPENSION BRIDGE WITH VARIABLE SUSPENSION TO MAIN SPAN RATIO
}

\author{
G. M. Savaliya ${ }^{1}$, A. K. Desai ${ }^{2}$, S. A. Vasanwala ${ }^{3}$ \\ ${ }^{I}$ Assistant Professor, Civil Engineering Department, Government Engineering College, Surat, Gujarat, India \\ ${ }^{2}$ Professor, Applied Mechanics Department, SVNIT, Surat, Gujarat, India \\ ${ }^{3}$ Professor, Applied Mechanics Department, SVNIT, Surat, Gujarat, India
}

\begin{abstract}
The demand of long span bridge is increasing with infrastructure magnification. To achieve maximum central span in bridges is a motivating rational challenge. The bridge with more central span can be achieved using high strength materials and innovative forms of the bridges. The cable-stayed bridge has better structural stiffness and suspension bridge has ability to offer longer span thus combination of above two structural systems could achieve very long span cable-stayed suspension hybrid bridge. To distinguish behaviour and check the feasibility of this innovative form of hybrid bridge, $1400 \mathrm{~m}$ central span and $312 \mathrm{~m}$ side span cable-stayed suspension hybrid bridge is considered for analysis. The suspension portion length in central span is also playing important role in behaviour of the entire bridge. Bridge behaviour is presented for variable length of suspension portion in form of suspension portion to main span ratio. The main cable sag in central span is playing important role on behavior of the entire bridge. It directly influences the inclination angles of the main cables, the height of pylon and thus forces in pylon. The axial force in main cable is directly depending on the sag of main cable. The effects of main cable sag is studied by considering dimensionless parameter as sag to main span ratio as 1/9, 1/10 and 1/11. Paper also discusses results of nonlinear static analysis and modal analysis carried out using SAP2000 v14.0.0. The time period of bridge is used to present the behavior of bridge.
\end{abstract}

Key Words: Cable supported long span bridge; cable stayed suspension hybrid bridge; cable sag to main span ratio; dynamic analysis

\section{INTRODUCTION}

The long span bridge is the demand of the modern day. To achieve medium or long span bridge cable supported bridges are used. As per the form of the bridge, the cable supported bridges can be subdivided in to cable stayed bridges and suspension bridges. Long span bridges can be achieved using high strength steel cables as a key force resisting structural element. Use of high strength steel cables leads to provide a competitive solution for spans between $200 \mathrm{~m}$ to $2000 \mathrm{~m}$.

Border line for a maximum span in bridges is determined by the strength, stiffness and density of materials. So, a high strength material is one area of research and many scientists had worked a lot in that area. The cable-stayed bridge and the suspension bridges, although similar in philosophy and have many differences in practice. One of the main reasons for their advantages in relation to other forms of bridge is the most efficient way in which the systems use materials, i.e. direct stress under which all the fibers have the same stress resulting in full utilization of the material. Some aspects of cable supported bridges are illustrated here.

\subsection{Suspension Bridge}

A deck of suspension bridge is hanged by vertical hangers, which are connected to main suspension caternary cables.
The main cable is continuous, over saddles at the pylons, or towers, from anchorage to anchorage. In a suspension bridge, a procedure to find the initial configuration under dead load is relatively simple as the main extremities are fixed at earth constraints.

As an outcome, optimization techniques are frequently employed with the purpose to identify the structural behavior of the bridge with respect more complex external loads such as aeroelastic and seismic phenomena. However, most of the methodologies are typically concerned to evaluate optimum post-tensioning forces in the dead load (DL) configuration, without achieving the complete optimization of the geometry, the stiffness of the structural elements and thus the costs of construction.

\subsection{Cable-Stayed Bridge}

In the cable-stayed bridges, the deck is supported by the inclined stayed cables. Cable-stays support the bridge deck throughout its length, the closeness cables reduces the required depth and stiffness of the longitudinal girder to a least and hence allowing the structure of comparatively long span. In the cable-stayed bridge load of the deck is transferred to pylon through cable stays and from pylon it is transfer to foundation. The structural members like cable stays and deck are subjected to tensile forces and decks and 
pylons are subjected to compressive forces. In deck the effect of bending and shear is less influential. For cablestayed bridge an iterative approach in which initially the post-tensioning cable forces in the DL configuration are determined by solving compatible conditions arising from flexibility matrix of the structure. In the cable-stayed bridge a cable-stays are making variable angles with horizontal axis, so the forces in the cable-stays are incompatible at different locations. So, the optimization procedure is utilized to minimize the cross-sections of the cable system, on the basis of the maximum effects on stress and displacement variables evaluated on the live load configurations.

The requirement of incredible long span bridges is increased day by day with increase in inhabitants and their needs. To achieve a very long span bridge, use of high strength material along with novel structural system is essential. In general to achieve longer span bridges, cable-stayed and suspension systems are used, in which the cable-stayed bridge has better structural stiffness and suspension bridge has ability to offer longer span. Combination of above two structural systems could achieve a very long span cablestayed suspension hybrid bridge.

\subsection{Cable-stayed suspension hybrid bridge}

The cable-stayed suspension hybrid bridge is presented as an alternative to long span cable-stayed and suspension bridges. Hybrid cable-stayed suspension bridge is combination of cable-stayed bridge and suspension bridge as shown in Fig. 1.

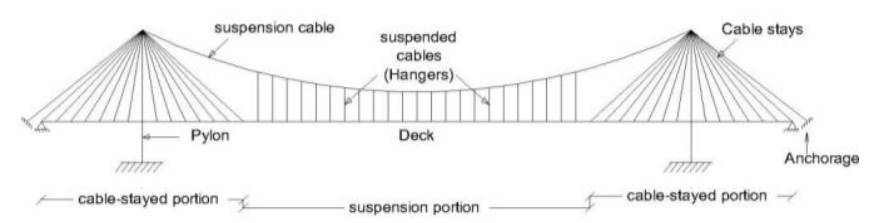

Fig. 1 hybrid cable-stayed suspension bridge

The idea for this innovative system was first introduced by Dischinger in 1949, Schlaich 1988; Gimsing 1988; Lin and Chow 1991.[1] There after a very little work is done on this system of combined bridge.

\subsubsection{Advantages of Cable-stayed suspension hybrid bridge}

Advantages of combining both the systems were discussed below. By combining both the system of cable supported bridges following advantages could be achieve:

1. In the innovative form of hybrid bridge the suspension portion could be reduced effectively by replacement of suspenders by cable stays, which reduced the axial force in the main cables.

2. As the suspension portion in the hybrid bridge is reduced the cost of main cable construction and massive anchorage is also reduced effectively.

3. As compared to cable-stayed bridges with the same span length, the number of cable stays is also greatly reduced.
These results, the reduced height of tower, length of stays and the axial forces in the deck.

4. In addition to these, cantilevers during erection are also shorted and wind stability of the bridge under construction may therefore improve.

Therefore Hybrid cable-stayed suspension bridge becomes an attractive alternative in the design of long span bridge systems.

\subsubsection{Analysis of Hybrid Cable-Stayed Suspension Bridge}

The analysis of cable-stayed suspension hybrid bridge is a new area of research. The hybrid bridge is consists of the main cables, cable-stays and hangers in a bridge, which present better performances than conventional ones based on pure suspension and cable-stayed configurations. Long span cable supported bridge highly are defined through large number of cable elements which lead to highly statically indeterminate structures. So, post tensioning forces in cables and cross sectional area of the cables can be considered as design variables, which must be determined to identify the bridge configuration under dead and live loading for economical structural steel quantity and optimum performance of structural elements.

\section{LITERATURE SURVEY}

Most of the existing cable supported bridges are designed by using traditional techniques, in which iterative methods based on simple design rules obtained by designer's experience and expertise were utilized [2]. During the last decades, many research efforts are carried out with the aim to propose proper procedure to calculate the optimum configuration of bridge. In particular zero displacement methods are based on the use of explicit constraint equations, which enforce the bridge structure under dead loading to remain practically unreformed.

Konstantakopoulos et. al. anticipated a numerical model to investigate the dynamic behaviour of a combined cable system of bridges under moving loads. The bridge's deformation under the action of moving loads was also studied [3]. Lewis presented an advanced mathematical model for the assessment of comparative material costs of the supporting elements for cable stayed and cable suspension bridges. Assessment of material supplies for each type of bridge across a range of span/dip ratios are presented in paper [4]. Lonetti et. al. proposed a methods to forecast best post-tensioning forces and dimensioning of the cable system for hybrid cable stayed suspension (HCS) bridges [5].

Zhang et. al. has work out the limit span of self-anchored cable-stayed suspension bridge. The relations among the geometrical parameters, loads and material characteristics are also analyzed [6]. Zhang presented the mechanics performance including the static and dynamic characteristics of $1400 \mathrm{~m}$ main span cable-stayed suspension Hybrid Bridge. The aerostatic and aerodynamic stability etc. is 
investigated by 3D nonlinear analysis [7]. Zhang et. al. presented analysis of a self-anchored cable-stayedsuspension bridge with best possible cable tensions under stationary loads. Finally, the Zhuanghe Jianshe Bridge was analysed to point out the design problems that require special attention.[8].

Zhang et.al. discussed aerodynamic stability of a $1400 \mathrm{~m}$ main span cable-stayed-suspension (CSS) hybrid bridge. Here, three-dimensional nonlinear aerodynamic stability analysis applied to study the behavior of innovative from of hybrid bridge. Authors suggest from the analysis carried out that the short suspension portion in main span is aerodynamically favorable [9]. Zhang studied the design parameters of Hybrid Cable-stayed Suspension Bridge with main span of $1400 \mathrm{~m}$ by considering the geometric nonlinearity of the bridge structures. It was found from study that as some design parameters are helpful for improving the flutter stability [10]. Zhang et.al. investigated the wind stability by analyzing a hybrid bridge with main span of $1400 \mathrm{~m}$. The optimal values of design parameters are determined Utilizing 3D nonlinear aerostatic and aerodynamic analysis [11].

Mu et. al. discussed the dynamic characteristics and seismic responses of new type of self anchored cable stayed suspension bridge. The research work covers the natural vibration frequencies and principal modes of the bridge [12]. From the literature it is found that the work related to the static and dynamic analysis of cable-stayed suspension hybrid bridge with variable length of suspension portion is inadequate. So, attention is need towards the nonlinear static and nonlinear dynamic analysis of cable-stayed suspension hybrid bridge. Hence, the current work is committed towards the nonlinear static and modal analysis of cablestayed suspension hybrid bridge.

\section{BRIDGE CONFIGURATION}

In current paper the behavior of $1400 \mathrm{~m}$ central span cablestayed suspension hybrid bridge presented for different suspension to main span ratio as $0.4,0.5$ and 0.6.

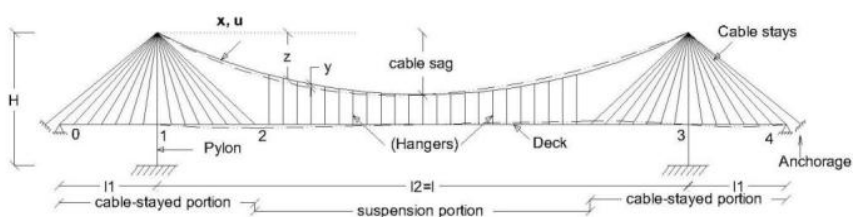

Fig. 2 hybrid cable-stayed suspension bridge configuration

The bridge has side span $l_{l}$ and a central span $l_{2}$ as shown in Fig.2. The dynamic analysis of cable-stayed suspension hybrid bridge is carried out with finite element method using SAP2000 V.14 software.

The bridge configuration considered in the current study is based on bridge of the east channel of Lingding Strait in China [13] having central $\mathrm{span}=1400 \mathrm{~m}$, two side spans $=$ $319 \mathrm{~m}$ and height of pylon=258.986 $\mathrm{m}$. The behavior of bridge is studied for different cable configuration and thus pylon height is considered as a constant.

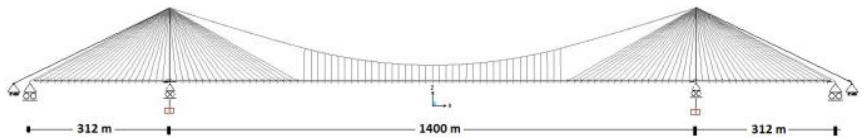

Fig.3 Geometric configuration of cable-stayed suspension hybrid bridge (CSSHB)

In current study as shown in Fig.3, the bridge having central span $=1400 \mathrm{~m}$, two side spans $=312 \mathrm{~m}$ and pylon height $=$ $258.986 \mathrm{~m}$ is studied with different suspension to span ratio. Length of suspension portion in central span is considered as key design aspect and considered ratio and corresponding length is presented in Table 1 .

Table 1: Suspension portion to main central span ratio and relevant length of suspension portion

\begin{tabular}{|l|l|l|l|}
\hline $\begin{array}{l}\text { The suspension portion to main span } \\
\text { ratio }\end{array}$ & 0.4 & 0.5 & 0.6 \\
\hline $\begin{array}{l}\text { Length(m) of suspension portion in } \\
\text { centre of bridge }\end{array}$ & 560 & 700 & 840 \\
\hline
\end{tabular}

Table 2 shows the material properties of different elements of bridge.

Table 2: Cross-sectional properties of cable-stayed suspension hybrid bridge members [7]

\begin{tabular}{|c|c|c|c|c|c|c|c|}
\hline Members & $\begin{array}{c}\mathrm{E} \\
(\mathrm{Mpa})\end{array}$ & $\begin{array}{c}\mathrm{A} \\
(\mathrm{m} 2)\end{array}$ & $\begin{array}{c}\mathrm{Jd} \\
(\mathrm{m} 4)\end{array}$ & $\begin{array}{c}\mathrm{Iy} \\
(\mathrm{m} 4)\end{array}$ & $\begin{array}{c}\mathrm{Iz} \\
(\mathrm{m} 4)\end{array}$ & $\begin{array}{c}\mathrm{M} \\
(\mathrm{Kg} / \mathrm{m})\end{array}$ & $\begin{array}{c}\mathrm{Jm} \\
\left(\mathrm{Kg} \cdot \mathrm{m}^{2} /\right. \\
\mathrm{m})\end{array}$ \\
\hline Girder & $2.1 \times 10^{5}$ & 1.761 & 3.939 & 193.2 & 8.33 & 26340 & $\begin{array}{c}2.957 \times 10 \\
6\end{array}$ \\
\hline Tower C & $3.3 \times 10^{4}$ & 30 & 350 & 220 & 320 & 78000 & $5.7 \times 10^{5}$ \\
\hline $\begin{array}{c}\text { Tower } \\
\text { TB }\end{array}$ & $3.3 \times 10^{4}$ & 10 & 150 & 70 & 70 & 26000 & $4.7 \times 10^{5}$ \\
\hline $\begin{array}{c}\text { Main } \\
\text { Cable CS }\end{array}$ & $2.0 \times 10^{5}$ & 0.3167 & - & - & - & 2660.3 & - \\
\hline $\begin{array}{c}\text { Main } \\
\text { Cable SS }\end{array}$ & $2.0 \times 10^{5}$ & 0.3547 & - & - & - & 2979 & - \\
\hline $\begin{array}{c}\text { Hanger } \\
\text { Cable }\end{array}$ & $2.0 \times 10^{5}$ & 0.0064 & - & - & - & 50.2 & - \\
\hline $\begin{array}{c}\text { Stayed } \\
\text { cables }\end{array}$ & $2.0 \times 10^{5}$ & vary & - & - & - & vary & - \\
\hline
\end{tabular}

Where, E - Modulus of Elasticity; A - Cross section area; M - Mass per unit length; Jd - torsional constat; Iy-Lateral Bending moment of inertia; Iz-Vertical Bending moment of inertia; Jm - mass moment of inertia per unit length

The simplified three-dimensional FE model of the bridge is developed using elastic beam and link elements. The bridge deck is modeled by a single central spine with offset rigid links to accommodate cable and hanger anchor points. The three dimensional steel beam elements are used to model the deck, towers, and beams of the towers. The Link elements are used to model the rigid links. The cables are modeled by tension-only cable elements that have a stress stiffening capability. The cable pretensions are considered to ensure small deformations under the deck self-weight. The main catenary cable is modeled as cable elements having sag to span ratio as variable.

For Suspension bridge and cable-stayed suspension hybrid bridge (CSSHB) the cable sag being important design 
parameter, which directly influences the inclination angles of the main cables and the height of pylon and thus forces in pylon. Sag of main cable is influence to the tensile forces in the main cables and ultimately affects structural stiffness and dynamic characteristics of bridge.

The behavior of CSSHB with variable elevation of main cable sag is studied in the current paper. The sag of main cable is chosen as ratio of cable sag to main span ratio. The cable sag is considered as dimensionless parameter as cable sag to main span ratio as presented in the following Table 3.

Table 3: Cable sag considered for analysis of $1400 \mathrm{~m}$ main span hybrid cable-stayed suspension bridge

\begin{tabular}{|c|c|c|c|}
\hline $\begin{array}{c}\text { Sag to main } \\
\text { span ratio }\end{array}$ & $1 / 9$ & $1 / 10$ & $1 / 11$ \\
\hline $\begin{array}{c}\text { Sag depth } \\
(\mathrm{m})\end{array}$ & 156 & 140 & 127 \\
\hline
\end{tabular}

The cable-stays are used for connecting deck to pylon at different locations of central span and side span of considered hybrid bridge. The force in cable-stays is increased as the length and angle of cable-stays with pylon is increased. So to meet the force requirements, the size of cable-stays in form of diameter $(\mathrm{mm})$ is selected as shown in Fig.3.

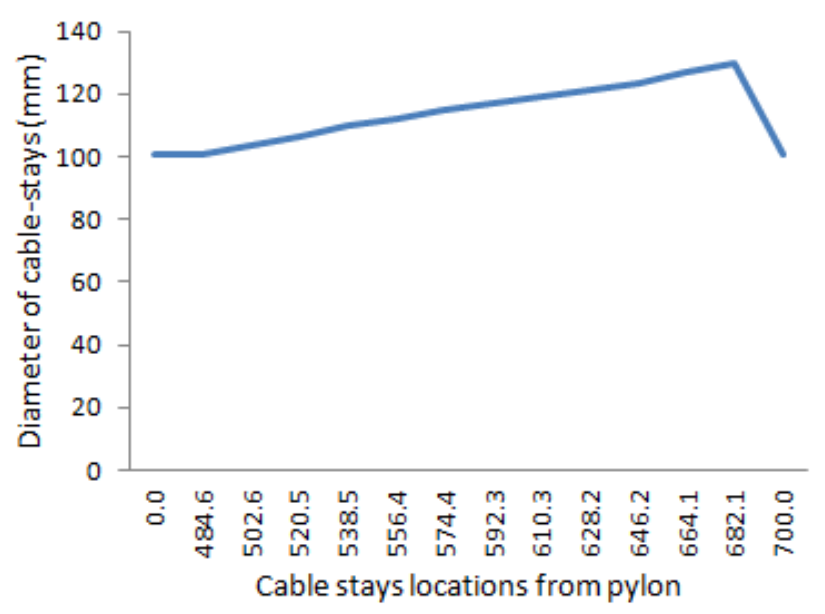

Fig.3 Cable-stays diameter at different locations in side span and central span from pylon

The connection between deck and pylon is assumed to be fixed against translation in the vertical and transverse directions and fixed against rotation about the longitudinal axis. The pylon footings are considered to be fixed against both translation and rotation. The ends of the bridge deck are supported by anchor piers make connection roller in longitudinal direction as the basic support condition. This leads to a self anchored bridge system.

\section{LOAD CASES}

Different elements of bridge are subjected to different types of loads like dead load, SIDL, live load etc. In the current study load cases considered are as shown in Table below 4 .
Table 4: different loads assigned to the different members

\begin{tabular}{|l|c|c|}
\hline Type of the load & $\begin{array}{c}\text { Value of } \\
\text { Assigned Load }\end{array}$ & $\begin{array}{c}\text { Element } \\
\text { Assigned }\end{array}$ \\
\hline Dead Load & $97.980 \mathrm{kN} / \mathrm{m}$ & Deck \\
\hline SIDL & $50.0 \mathrm{kN} / \mathrm{m}$ & Deck \\
\hline Live Load & $34.650 \mathrm{kN} / \mathrm{m}$ & Deck \\
\hline
\end{tabular}

\section{STATIC AND DYNAMIC BEHAVIOR}

One of the important features of cable supported bridges is influence of the dead load on the stiffness of bridge. To include this influence, the static analysis under self-weight and cable pretension is performed. The sag effect is considered to include geometrical nonlinearity in the static analysis. Nonlinear static and dynamic analyses are carried out to determine the response of the cable-stayed suspension hybrid bridge.

The P-Delta effect can be a very important contributor to the stiffness for considering geometrical nonlinearity of cable structures. The lateral stiffness of cables is due almost entirely to tension, since they are very flexible when unstressed. It is important to use realistic values for the Pdelta load combination, since the lateral stiffness of the cables is approximately proportional to the P-delta axial forces.

Dynamic behavior of bridge can conclude by dynamic analysis. Hence, Modal analysis is carried out to recognize the dynamic behavior of bridge. In modal analysis each modal load case results in a set of modes. Each mode consists of a mode shape (normalized deflected shape) and a set of modal properties like Time periods and Frequencies of the structure. Results are presented for different length of suspension to main span ratio for cable-stayed suspension hybrid bridge.

\subsection{Significance of Result Parameters on Behaviour of Bridge}

Structure's displacement and load parameters could consider finding behaviour and feasible cable sag and central suspension portion of cable-stayed suspension hybrid bridge. The static nonlinear load case and the modal load case are considered in the current study for assessment of subsequent result parameters.

1. Time period in lateral, longitudinal and vertical mode shapes of cable-stayed suspension hybrid bridge with different cable sag along with variable suspension to main span ratio.

2. Time period of $1^{\text {st }}, 2^{\text {nd }}$ and $3^{\text {rd }}$ mode of main catenary cables and lateral mode shapes of pylon for different cable sag along with suspension to main span ratio.

\subsection{Effects of The Main Cable Sag on Dynamic Behaviour of Bridge}

To understand of how cable sag affects the dynamic behavior of CSSHB, dynamic analysis of bridge is carried out with different cable sag. The effect of length of 
suspension portion is also considered in from of different suspension to main span ratio. The results of dynamic analysis is presented in the form of time period in lateral, vertical, longitudinal direction, and cable mode shapes as presented in the given below Table 5, 6 and 7 for suspension to main span ratio $0.4,0.5$ and 0.6 respectively.

Table 5: Time period of CSSHB with suspension/span $=0.4$

\begin{tabular}{|c|c|c|c|}
\hline Mode Shapes & $\begin{array}{c}\text { Sag/span } \\
(1 / 9)\end{array}$ & $\begin{array}{c}\text { Sag/span } \\
(1 / 10)\end{array}$ & $\begin{array}{c}\text { Sag/span } \\
(1 / 11)\end{array}$ \\
\hline Cable Sag (m) & 156 & 140 & 127 \\
\hline Deck Lateral -1 & 13.35 & 12.85 & 13.16 \\
\hline Deck Vertical_1 & 5.52 & 5.09 & 5.32 \\
\hline Deck Longi._1 & 5.28 & 4.72 & 4.64 \\
\hline Main Cable_1 & 7.51 & 7.38 & 7.68 \\
\hline
\end{tabular}

Table 6: Time period of CSSHB with suspension/span $=0.5$

\begin{tabular}{|c|c|c|c|}
\hline Mode Shapes & $\begin{array}{c}\text { Sag/span } \\
(1 / 9)\end{array}$ & $\begin{array}{c}\text { Sag/span } \\
(1 / 10)\end{array}$ & $\begin{array}{c}\text { Sag/span } \\
(1 / 11)\end{array}$ \\
\hline Cable Sag (m) & 156 & 140 & 127 \\
\hline Deck Lateral -1 & 13.16 & 12.79 & 12.99 \\
\hline Deck Vertical_1 & 5.26 & 5.20 & 5.73 \\
\hline Deck Longi.11 & 5.10 & 4.81 & 5.00 \\
\hline Main Cable_1 & 6.95 & 7.05 & 7.88 \\
\hline
\end{tabular}

Table 7: Time period of CSSHB with suspension/span=0.6

\begin{tabular}{|c|c|c|c|}
\hline Mode Shapes & $\begin{array}{c}\text { Sag/span } \\
(1 / 9)\end{array}$ & $\begin{array}{c}\text { Sag/span } \\
(1 / 10)\end{array}$ & $\begin{array}{c}\text { Sag/span } \\
(1 / 11)\end{array}$ \\
\hline Cable Sag (m) & 156 & 140 & 127 \\
\hline Deck Lateral -1 & 12.96 & 12.65 & 12.82 \\
\hline Deck Vertical_1 & 5.27 & 5.36 & 5.82 \\
\hline Deck Longi._1 & 5.51 & 5.22 & 5.40 \\
\hline Main Cable_1 & 6.56 & 6.84 & 7.44 \\
\hline
\end{tabular}

\section{CONCLUSIONS}

The dynamic analysis of the cable-stayed suspension hybrid bridge is carried out with aspect considered as cable sag of the main cables as well as the suspension portion in cablestayed suspension hybrid bridge. The results obtained from the analysis is presented in the above tables in the form of principal mode shape time period of bridge in lateral, vertical, longitudinal and cable mode shape.

1. The lateral bending mode time period of cable-stayed suspension hybrid bridge is found to be minimum in case of sag to main span ratio is $1 / 10$ (Cable sag=140m) and suspension to main span ratio is 0.6 .

2. It is also found from the results obtained that, the time period of the bridge is decreasing with the suspension portion is increased from 0.4 to 0.6 .

3. It is also found from the tables that, time period of the bridge in lateral bending is reduced with a decrease in the cable sag.
4. The 1st vertical bending mode shape time period is found to be minimum in CSSHB with cable sag to main span ratio is $1 / 10$ (Cable sag $=140 \mathrm{~m}$ ) and suspension to main span ratio is 0.5 . Vertical bending mode time period is increased with reduce cable sag.

5. The longitudinal bending mode time period of bridge decreases with decrease in cable sag. The reason for the enhancement of bridge stiffness with a decrease in cable sag is the length of flexible main cable.

6. The cable time period of CSSHB is increased with reduce in cable sag.

\section{REFERENCES}

[1] STAROSSEK U., "Cable Stayed Bridge Concept of Longer Spans”, Journal of Bridge Engg., Aug, Vol-1, 99-103, 1996.

[2] WALTER Rene et. al. (1988), "Cable-stayed Bridges" Thomas Telford, London.

[3] KONSTANTAKOPOULOS T.G. and MICHALTSOS G.T., "A mathematical model for a combined cable system of bridges" Engineering Structures 32 (2010) 2717-2728.

[4] LEWIS W. J., "A mathematical model for assessment of material requirements for cable supported bridges: Implications for conceptual design", Engineering Structures 42 (2012) 266-277.

[5] LONETTI P. \& PASCUZZO A., "Optimum design analysis of hybrid cable-stayed suspension bridges", Advances in Engineering Software, 73 (2014) 53-66.

[6] ZHANG Zhe et. al., "Limit span of self-anchored cablestayed suspension cooperation System Bridge based on strength", Front. Archit. Civ. Eng. China, 3(3), (2009), pp.286-291.

[7] ZHANG Xin-Jun "Investigations on mechanics performance of cable-stayed suspension hybrid bridges", Wind and Structures, Vol. 10, No. 6 (2007), pp. 533-542.

[8] ZHANG Zhe et al. , "Static Analysis of a Self-anchored Cable-stayed-suspension Bridge with Optimal Cable Tensions" JOURNAL OF C.C.I.T, VOL.39, NO.2, NOV., 2010.

[9] ZHANG Xin-jun, "Aerodynamic stability of cablestayed-suspension hybrid bridges", Journal of Zhejiang University SCIENCE, 6A(8), (2005), pp. 869-874.

[10]ZHANG Xin-jun, "Study of design parameters on flutter stability of cable -stayed -suspension hybrid bridges", Wind and Structures, Vol. 9, No. 4, (2006), pp. 331-344.

[11]ZHANG X.J. and DAVID A. Stern, "Wind-resistant design of cable-stayed-suspension hybrid bridges", Transportation and Development Innovative Best Practices 2008, (TDIBP2008) pp. 444-449.

[12] MU Y N et. al., "Seismic Responses Analysis of a Selfanchored Cable-stayed Suspension Bridge", International Conference on Transportation Engineering 2009 (ICTE 2009), pp. 1692-1698. 2009 ASCE.

[13]XIAO, R.C., "Research on design of cable-stayed suspension hybrid bridges", China civil engineering journal, 33(5), (2000), pp.46-51. 